\title{
Effect of Process Conditions on the Physicochemical Properties of Fermented Beet Root Juice Powder Produced by Spray Drying
}

\author{
Priti Jain $^{1 *}$, A.K. Gupta ${ }^{1}$, M.K. Pathak ${ }^{2}$ and Nidhi Khanna ${ }^{1}$ \\ ${ }^{1}$ Department of Post-Harvest Process and Food Engineering, College of Agricultural \\ Engineering, JNKVV, Jabalpur, India \\ ${ }^{2}$ College of Fisheries Engineering, Tamil Nadu, India \\ *Corresponding author
}

\section{A B S T R A C T}

\begin{tabular}{|l|}
\hline Ke y w o r d s \\
$\begin{array}{l}\text { Spray drying, Beet } \\
\text { root, Maltodextrin, } \\
\text { Betalain, Powder } \\
\text { quality, }\end{array}$ \\
Fermentation \\
\hline Article Info \\
\hline $\begin{array}{l}\text { Accepted: } \\
\text { 28 October } 2017 \\
\text { Available Online: } \\
\text { 10 December } 2017\end{array}$ \\
\hline
\end{tabular}

Beet root (Beta vulgaris L.) has many applications in the food and pharmaceutical sectors as an additive. It is a health-promoting vegetable and is valued for its natural colour and medicinal properties. Effect of air flow rate and feed flow rate on the moisture content, bulk density, solubility, hygroscopicity, betalain content and product recovery of the fermented beet root juice powder was investigated. The beet root juice was fermented at $25^{\circ} \mathrm{C}$ for $24 \mathrm{~h}$ with Saccharomyces cerevisiae, (MTCC 178). A central composite method was used to design the experiments and response surface methodology (RSM) was used for the optimization of spray drying of fermented beet root juice. All the experiments were conducted at a constant inlet air temperature $\left(144^{\circ} \mathrm{C}\right)$ and maltodextrin concentration $(5 \%)$. Air flow rate varied from 49.56 to $59 \mathrm{~m}^{3} / \mathrm{h}$ and feed flow rate varied from 120 to 150 $\mathrm{mL} / \mathrm{h}$. The optimized parameters for spray dried fermented beet root juice powder were obtained with the air flow rate of $57.92 \mathrm{~m}^{3} / \mathrm{h}$ and feed flow rate of $150 \mathrm{ml} / \mathrm{h}$ and corresponding responses were: moisture content (3.68\%), solubility (90.0\%), hygroscopicity $(0.186 \mathrm{~g} / \mathrm{g})$ bulk density $(0.455 \mathrm{~g} / \mathrm{ml})$, betalain content $(16.4 \%)$ and product recovery $(14.01 \%)$.

\section{Introduction}

Beetroot (Beta vulgaris L.) commonly known as 'chukander', is cultivated in India mainly for its juice and vegetable value. It yields on an average of 250 to 300 quintals/hectare of roots (www.agrifarming.in/beetroot-farming). The roots are blood red in colour with thin skin. Beetroot contains $7.96 \%$ sugar, $9.96 \%$ carbohydrate, $1.68 \%$ protein and $6 \mathrm{mg}$ of vitamin C per $100 \mathrm{~g}$ of pulp (Adda Bjarnadottir, 2015). It is also an excellent source of calcium, magnesium, copper, phosphorus, sodium and iron. The green leafy part of the beetroots is also of nutritional value, containing beta-carotene and other carotenoids. The green leaves have a higher content of iron compared to spinach. Deep red-colored beet roots are most popular for human consumption, both cooked and raw as salad or juice (Grubben and Denton, 2004).

To prolong the shelf life and better handling beet root juice can be converted into beet root powder. From beet root powder, juice can be prepared instantly whenever required. Beet root powder is reported to have medicinal properties, particularly to improve digestion 
and blood quality [Stintzing and Carle, (2004); Delgado-Vargas et al., (2000)]. It detoxifies the body faster and better than almost any other vegetable juice on earth. Inspite of medicinal qualities and rejuvenating heath benefits, few people include it in their daily diet.

Spray drying is one of the techniques used extensively in food industries. It is used under optimal processing conditions to obtain good quality powders. Fruit juice powders have many benefits and economic potentials over their liquid counterparts such as reduced volume or weight, reduced packaging, easier handling and transportation and much longer shelf life. Besides, their physical state powder provides a stable, natural and easily dosable ingredient, which generally finds usage in many foods and pharmaceutical products such as flavoring and coloring agents (Shrestha et al., 2007).

Spray drying of sugar rich foods such as fruit juices has great economical potential. Transformation of these products into a dry particulate form results in much reduced volume and longer shelf life. The reconstitution quality of spray-dried powder is also good as the processing temperature is rarely elevated above $100^{\circ} \mathrm{C}$ (Adhikari et al., 2004).

However, sugar rich fruit juice powders obtained by spray drying suffer from few drawbacks in their functional properties, such as stickiness, hygroscopicity and solubility thus making their packaging and utilization difficult.

Conventional processing of beet root powder which includes washing, peeling, slicing, drying and grinding is implicated with several quality and hygienic problems. The production conditions and the extended drying times promote the growth of bacteria and molds. Since spray-drying method facilitates continuous production of powder and completely eliminates manual handling, there are lesser chances of contamination in the final product.

A higher level of pigment concentration in powdered produce can be obtained through fermentation (Stephen, 2004). The fermentable solids present in beet juice can be removed in a biofermentor, using yeasts such as Candida utilis and Saccharomyces cerevisiae, to yield a concentrated pigment product.

Powders obtained after fermentation of beet juice contain five to seven times more betacynin than powders obtained from unfermented beet juice. Betalain extracts can have a range of colours, depending on the relative proportion of betacyanin and betaxanthin pigments present. Colouring products are usually odourless and tasteless, but they can impart odour and flavour to food. The most important food colouring is pure betanin or beet root red, which is used to colour a wide range of processed food products.

Literature shows very limited work on the processing of beet root juice powder and demands for a detailed study regarding the engineering properties associated with spray drying such as the optimum air flow rate and feed flow rate to preserve the quality of beet root powder.

\section{Materials and Methods}

Fresh and fully mature beet roots were procured from local market. Maltodextrin (Maize based, National starch, Singapore) was used as carrier agent. Yeast strains namely Saccharomyces cerevisiae (MTCC 178) was procured from Institute of Microbial Technology, Chandigarh. 
Preparation of beet root juice and its spray drying

The fresh and matured beet roots were selected and washed thoroughly in lukewarm water to remove adhered foreign materials. The skin of beet root was peeled with the help of a hand peeler. The peeled beet roots were cut into small pieces and fed to a small capacity laboratory juicer to obtain the beet root juice. The juice was filtered through an $11 \mu \mathrm{m}$ nylon mesh and transferred into a glass beaker. The recovery of juice was around $55 \%$ of the fresh weight of beet roots.

The freshly prepared juice was thoroughly mixed with maltodextrin (5\%) with the help of magnetic stirrer and was filtered by 150 micron cloth filter to remove fibers. Filtered juice was then fermented with Sacchromyces cerevisiae (MTCC 178). The beet root juice was inoculated with $10 \%(\mathrm{v} / \mathrm{v})$ inoculums of culture and incubated at $25{ }^{\circ} \mathrm{C}$ for $24 \mathrm{~h}$.

A Labultima lab spray dryer (LU-222 Advanced Model, Twin Cyclone) was employed for the spray drying of fermented beet root juice (Fig. 1). Spray drying was carried out at the inlet air temperatures of 144 ${ }^{\circ} \mathrm{C}$ and outlet temperature of $70{ }^{\circ} \mathrm{C}$. Effect of air flow rate (viz, 49.56, 51.92, 54.28, 56.64 and $59.0 \mathrm{~m}^{3} / \mathrm{h}$ ) and feed flow rate (viz. 120 , $127.5,135.0,142.5$ and $150 \mathrm{ml} / \mathrm{h}$ ), on the physico-chemical property of spray dried beet root powder was investigated. All the spraydried powder was collected in clean glass container of known weight. The powder produced was weighed and sealed in bottle.

\section{Determination of physicochemical parameters of beet root powder}

\section{Moisture content}

Moisture content was determined by the digital moisture meter. One gram of each powder was placed in digital moisture meter at $100{ }^{\circ} \mathrm{C}$ for $10 \mathrm{~min}$.

\section{Solubility}

The solubility of powder was determined by the procedure recommended by Eastman and Moore (1984).

\section{Hygrscopicity}

About $1 \mathrm{~g}$ of powder was spread evenly on Petri dishes $(9 \mathrm{~cm}$ diameter) to allow for a high surface area between humid air and powder. Samples of each powder were placed in respective separate dishes in desiccator at $23^{\circ} \mathrm{C}$ and $76 \%$ relative humidity using $\mathrm{HNO}_{3}$ solution. Ten minutes interval was selected to get the kinetics of moisture sorption (AlKahtani and Hassan, 1990).

\section{Bulk density}

Bulk density $(\mathrm{g} / \mathrm{mL})$ was determined by gently adding $2 \mathrm{~g}$ of powder into an empty 10 $\mathrm{mL}$ graduated cylinder. The ratio of powder mass and the volume occupied in the cylinder determines the bulk density value (Goula et al., 2004).

\section{Betalain content}

Betalain content of beet root juice were estimated by a spectrophotometric method (Wyter and Dreiding, 1957; Platteelli and Minale, 1964).

\section{Product recovery}

The product recovery was calculated with following equation by Chegini and Ghobadian (2007).

$$
P R(\%)=\frac{M c .(1-X p)}{W s . C s . \theta} \times 100
$$


Where,

PR: product recovery $(\%)$

Mc: Mass collected by the cyclone $(\mathrm{kg})$

Xp: Loss on drying (\%)

Ws: Feed mass flow rate of the extract $(\mathrm{kg} / \mathrm{s})$

Cs: Solids content $(\mathrm{kg} / \mathrm{kg})$

$\theta$ : Processing time (s)

\section{Results and Discussion}

Effect of air flow rate and feed flow rate on the quality attributes of fermented beet root powder

\section{Moisture content}

The influence of air flow rate and feed flow rate on the moisture content of fermented beet root powder is shown in Figure 2. The moisture content of the beet root powder increases from 3.1 to $4.3 \%$ (w.b) when air flow rate increases from 49.56 to $59 \mathrm{~m}^{3} / \mathrm{h}$ for any constant feed flow rate within the range of 120 to $150 \mathrm{ml} / \mathrm{h}$. This may be due to the fact that higher air flow rate resulted in lesser residence time of beet root juice in the drying chamber and consequently larger amount of residual moisture in obtained beet root powder.

The feed flow rate affected the moisture content of beet root powder. An increase in feed flow rate from 120 to $150 \mathrm{ml} / \mathrm{h}$ increases moisture content from 2.8 to $3.4 \%$ (w.b) at any constant air flow rate within the range of 49.56 to $59 \mathrm{~m}^{3} / \mathrm{h}$. Higher feed flow rates results in a shorter contact time between the feed and drying air thus making the heat transfer less efficient thereby causing lower water evaporation.

\section{Solubility}

Solubility, as shown in Figure 3, decreases from 96.8 to $96.2 \%$ with an increase in air flow rate from 49.56 to $59 \mathrm{~m}^{3} / \mathrm{h}$ for any constant feed flow rate within the range of 120 to $150 \mathrm{ml} / \mathrm{h}$.

From Figure 2 it can be inferred that an increase in the air flow rate results in lesser residence time and thus higher residual moisture content in the obtained beet root juice powder.

The lower the powder moisture content, the more soluble the powder. Goula et al., (2004) also found that the powders with lower moisture content are more soluble.

An increase in feed flow rate from 120 to 150 $\mathrm{ml} / \mathrm{h}$ decreased solubility from 97.2 to $96.4 \%$ for any constant air flow rate within the range of 49.56 to $59 \mathrm{~m}^{3} / \mathrm{h}$. This is due to higher residual moisture content of the powder resulting in lower solubility of beet root powder.

\section{Hygroscopicity}

For any feed flow rate within the range of 120 to $150 \mathrm{ml} / \mathrm{h}$, an increase in air flow rate from 49.56 to $59 \mathrm{~m}^{3} / \mathrm{h}$ leads to a reduction in the hygroscopicity of the beet root powder from 0.25 to $0.18 \mathrm{~g} / \mathrm{g}$ (Fig. 4 ).

Higher air flow rate offers a shorter residence time in the drying chamber which results in a higher amount of residual moisture in obtained beet root powder causing a decrease in the hygroscopicity.

An increase in feed flow rate from 120 to 150 $\mathrm{ml} / \mathrm{h}$ decreases hygroscopicity from 0.23 to $0.21 \mathrm{~g} / \mathrm{g}$ for any constant air flow rate within the range of 49.56 to $59 \mathrm{~m}^{3} / \mathrm{h}$.

Lower feed flow rate decreases moisture content which causes greater capacity to absorb ambient moisture which results to decrease in hygroscopicity. 
Fig.1 Lab scale spray dryer

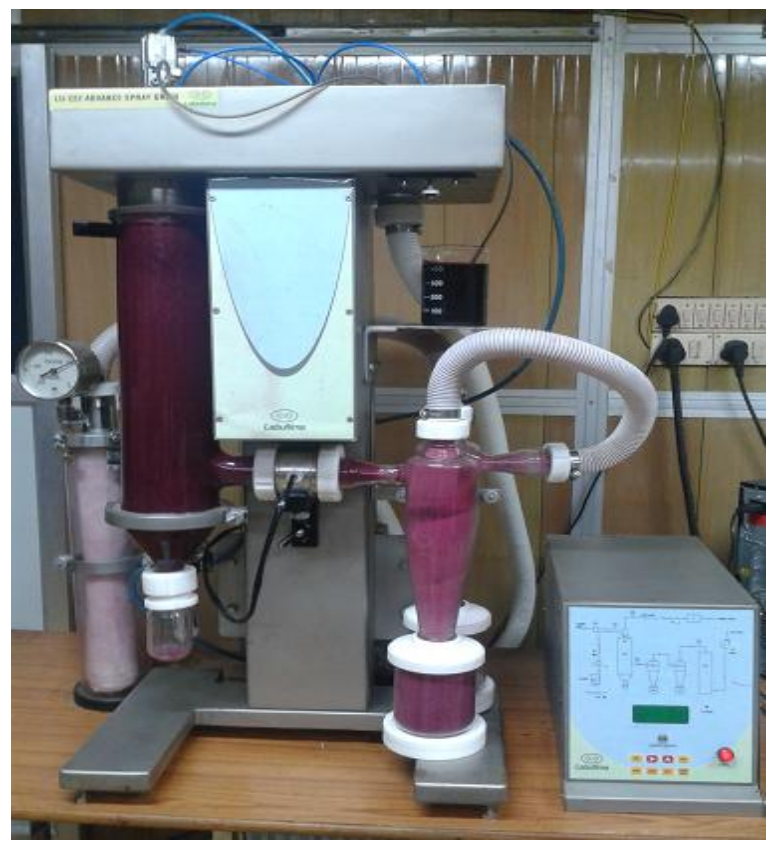

Fig.2 Effect of air flow rate and feed flow rate on the moisture content of spray dried beet root powder
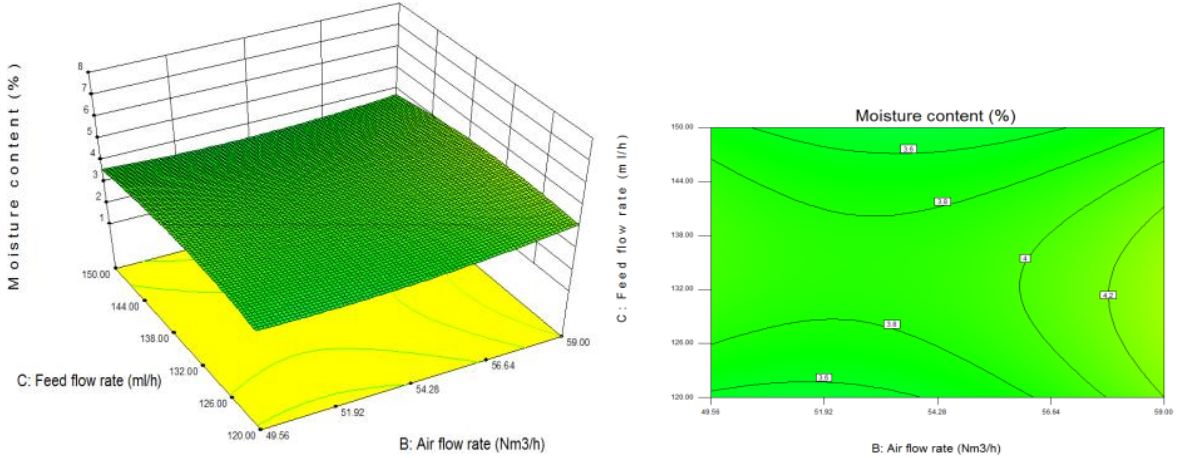

Fig.3 Effect of air flow rate and feed flow rate on the solubility of spray dried beet root powder
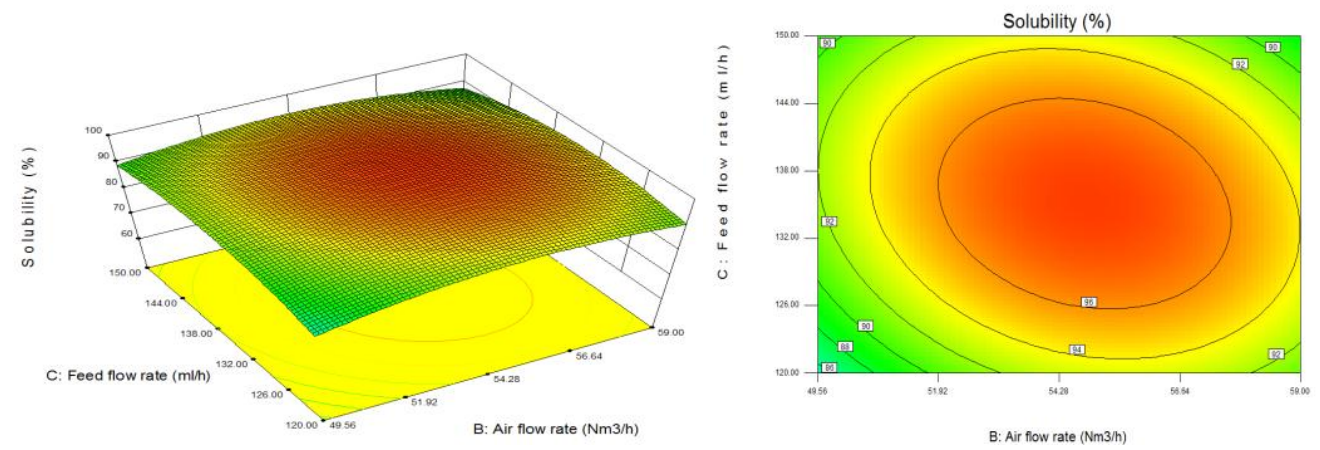
Fig.4 Effect of air flow rate and feed flow rate on the hygroscopicity of spray dried beet root powder
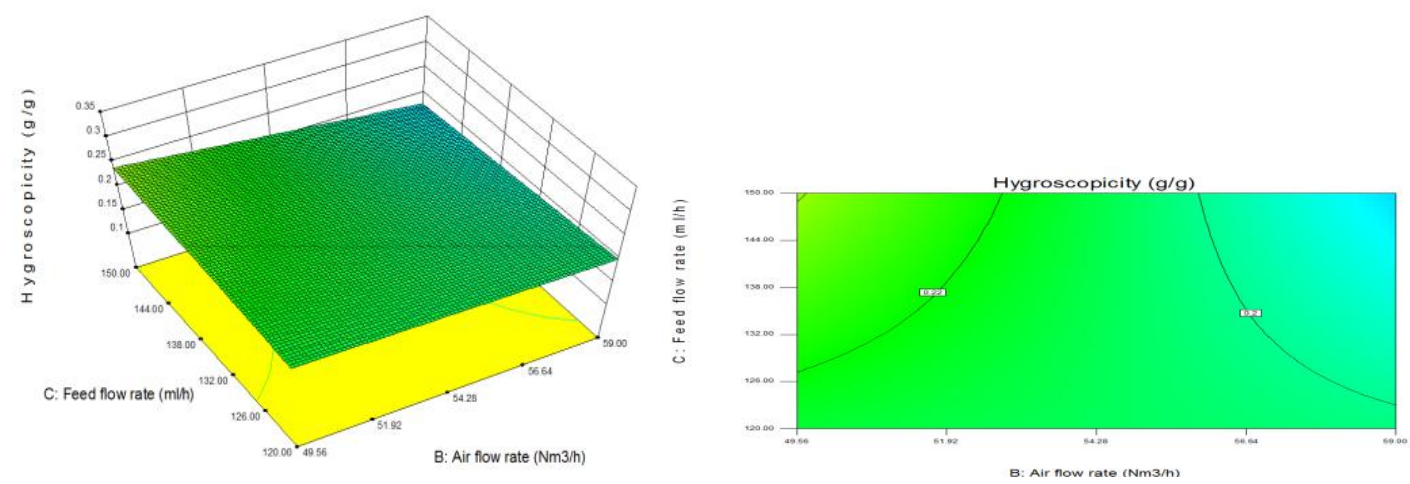

Fig.5 Effect of air flow rate and feed flow rate on the bulk density of spray dried beet root powder
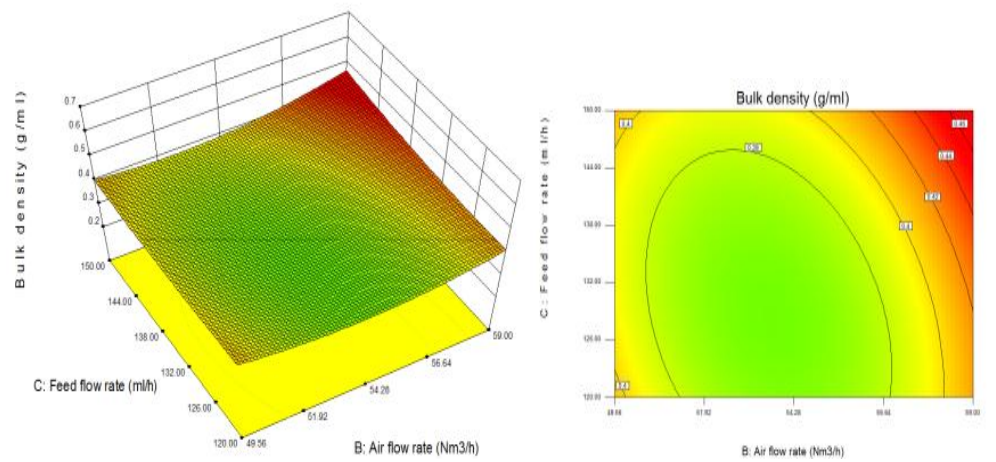

Fig.6 Effect of air flow rate and feed flow rate on the betalain content of spray dried beet root powder
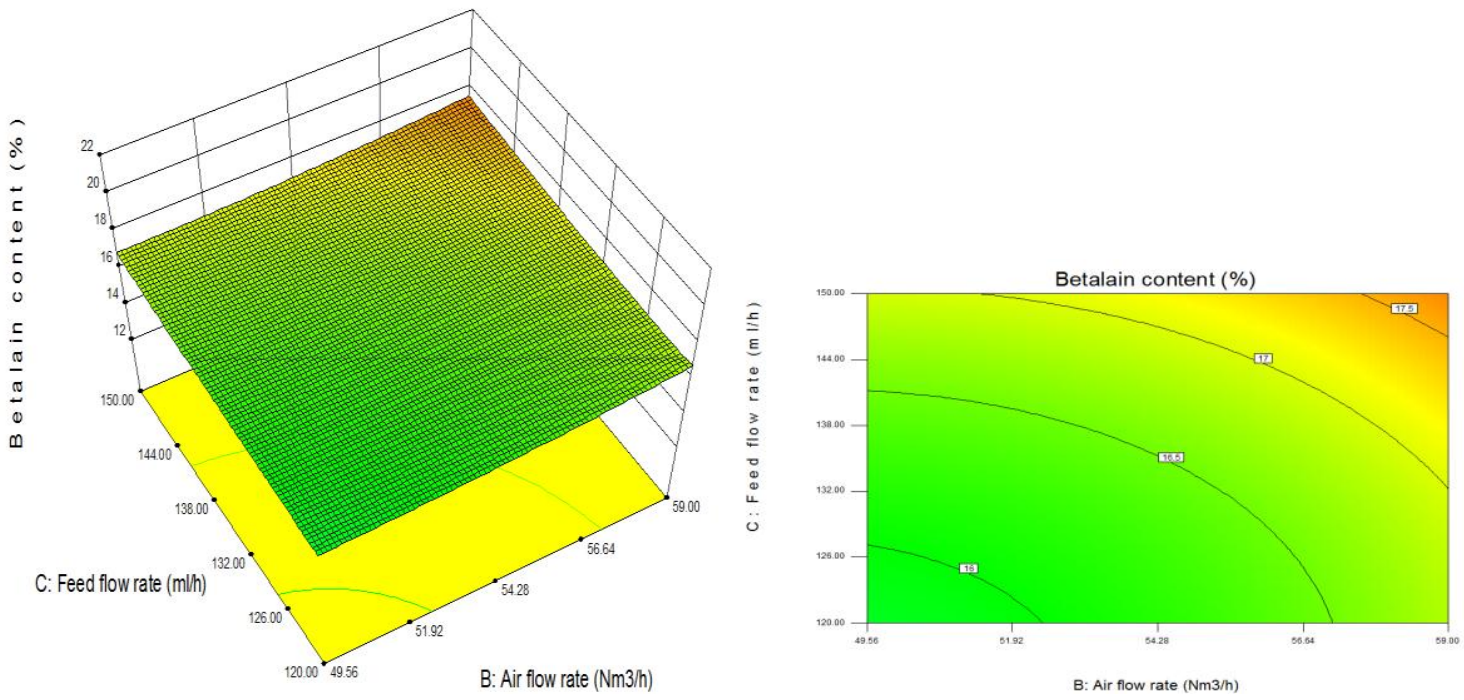
Fig.7 Effect of air flow rate and feed flow rate on the product recovery of spray dried beet root powder

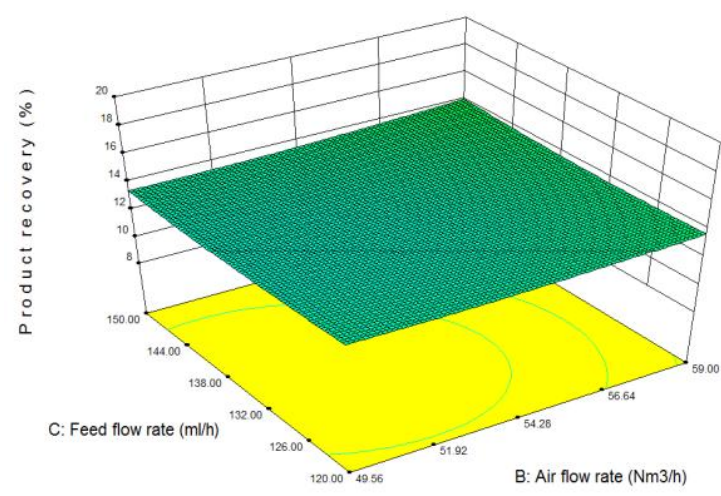

\section{Bulk density}

The bulk density of the beet root powder increases with an increase in the air flow rate and feed flow rate (Fig. 5). Bulk density of the beet root powder varied from 0.37 to 0.42 $\mathrm{g} / \mathrm{ml}$ with an increase in air flow rate from 49.56 to $59 \mathrm{~m}^{3} / \mathrm{h}$ for any constant feed flow rate within the range of 120 to $150 \mathrm{ml} / \mathrm{h}$. A lower air flow rate causes higher evaporation rate at other constant parameter due to more residence time which results in more porous or fragmented structure in beet root powder. An increase in volume of particle causes a decrease in the bulk density of powder. The higher moisture content in the powder increases bulk density of a dry product. This trend was also observed by Masters (1979b). The increase of feed flow rate from 120 to $150 \mathrm{ml} / \mathrm{h}$ increases bulk density from 0.32 to $0.41 \mathrm{~g} / \mathrm{ml}$ for any constant air flow rate within the range of 49.56 to $59 \mathrm{~m}^{3} / \mathrm{h}$. This may be due to higher moisture content of the beet root product.

\section{Betalain content}

The betalain content of the fermented beet root powder increased from 15.3 to $16.7 \%$ with an increase in air flow rate from 49.56 to $59 \mathrm{~m}^{3} / \mathrm{h}$ for any constant feed flow rate within the range of 120 to $150 \mathrm{ml} / \mathrm{h}$ (Fig. 6). A

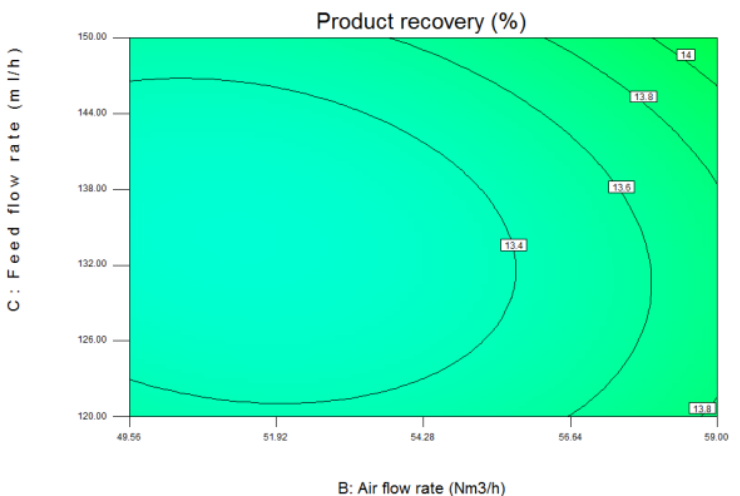

higher air flow rate causes lesser residence time which results in less degradation of betalain pigment in beet root powder. The betalain content of the powder increased from 15.6 to $16.4 \%$ when the feed flow rate increased from 120 to $150 \mathrm{ml} / \mathrm{h}$ for any constant air flow rate within the range of 49.56 to $59 \mathrm{~m}^{3} / \mathrm{h}$. This may be due to lesser residence time which results in higher betalain pigment in beet root powder.

\section{Product recovery}

The effect of air flow rate and feed flow rate on the product recovery of fermented beet root powder is presented in Figure 7. The product recovery of the beet root powder increases from 14.5 to $14.9 \%$ when air flow rate increases from 49.56 to $59 \mathrm{~m}^{3} / \mathrm{h}$ for any constant feed flow rate within the range of 120 to $150 \mathrm{ml} / \mathrm{h}$. Higher air flow rate resulted in higher product yield due to higher residual moisture of beet root powder. When feed flow rate increases from 120 to $150 \mathrm{ml} / \mathrm{h}$ for any air flow rate within the range of 49.56 to 59 $\mathrm{m}^{3} / \mathrm{h}$, the product recovery of the beet root powder decreases from from 14.9 to $14.6 \%$ due to product waste as a stickiness in a drying chamber.

Spray drying condition for fermented beet root juice was optimized in terms of process 
parameters (air flow rate and feed flow rate) for the lower moisture content and hygroscopicity, higher bulk density, solubility, betalain content and product recovery using RSM. The optimized parameters for spray dried fermented beet root juice powder were obtained with the air flow rate of $57.92 \mathrm{~m}^{3} / \mathrm{h}$ and feed flow rate of $150 \mathrm{ml} / \mathrm{h}$ and corresponding responses were: moisture content $(3.68 \%)$, solubility $(90.0 \%)$, hygroscopicity $(0.186 \mathrm{~g} / \mathrm{g})$, bulk density $(0.455 \mathrm{~g} / \mathrm{ml})$, betalain content $(16.4 \%)$ and product recovery $(14.01 \%)$.

\section{References}

Adda Bjarnadottir M.S., (2015). Beetroot 101: Nutrition facts and health benefitsAuthority Nutrition

Adhikari, B., Howes, T., Bhandari, R.B. and Troung. V., (2004). Effect of addition of maltodextrin on drying kinetics and stickiness of sugar and acid-rich foods during convective drying: experiments and modelling. Journal of Food Engineering, 62(1): 53-68.

Al-Kahtani, H. A., and B. H. Hassan. 1990. Spray drying of roselle (Hibiscus sabdariffa L.). J. Food Sci. 55(4):10731076.

Chegini GR, Ghobadian B. 2007. Spray dryer parameters for fruit juice drying. World Journal of Agricultural Sciences 3, 230 236.

Delgado-Vargas F, Jimenez AR, ParedesLopez O., (2000). Natural pigments: carotenoids, anthocyanins and betalains characteristics, biosynthesis, processing and stability. Food Sci Nutr. 40(3):173289.

Eastman, J. E. \& Moore, C. O. (1984). Cold water soluble granular starch for gelled food composition.

Grubben G.J.H. and Denton O.A., (2004). Plant Resources of Tropical Africa 2. Vegetables. PROTA Foundation, Wageningen, Backhuys, Leiden; CTA, Wageningen.

Masters, K. (1979). Spray drying fundamentals: Process stages and layouts. New York: Halsted Press.

Platteelli, M. and Minale, L., (1964). Pigments of centrospermae I. Betacynins from Phyllocactus hybridus Hort. and Opuntia ficus-indica Mill. Phytochemistry, 3:307-311.

Shrestha A.K. Ua-arak, T., Adhikari, B.R., Howes, T., and Bhandari, B.R., (2007). Glass transition behavior of spray dried orange juice powder measured by differential scanning calorimetry (DSC) and thermal mechanical compession test (TMCT). International Journal of Food Properties, 10, 661-673

Stephen Nottingham, (2004), Beet root (Ebook)

Stintzing F.C.; Carle R. (2004). Functional properties of anthocyanins and betalains in plants, food and in human nutrition. Trends in Food Science and Technology, Vol. 15(1):19-38.

www.agrifarming.in/beetroot-farming

Wyler, H. and Dreiding, A.S. (1957). Kristallisiertes betanin. Helvetica Chimica Acta 40: 191-192.

\section{How to cite this article:}

Priti Jain, A.K. Gupta, M.K. Pathak and Nidhi Khanna. 2017. Effect of Process Conditions on the Physicochemical Properties of Fermented Beet Root Juice Powder Produced by Spray Drying. Int.J.Curr.Microbiol.App.Sci. 6(12): 4209-4216. doi: https://doi.org/10.20546/ijcmas.2017.612.484 